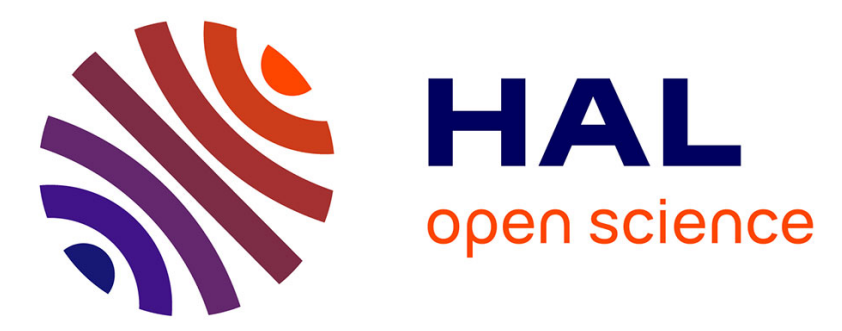

\title{
Impact of Anonymity and Identity Deception on Social Media eWOM
}

\author{
Payal Shrivastava Kapoor, Srinivas Gunta
}

\section{To cite this version:}

Payal Shrivastava Kapoor, Srinivas Gunta. Impact of Anonymity and Identity Deception on Social Media eWOM. 15th Conference on e-Business, e-Services and e-Society (I3E), Sep 2016, Swansea, United Kingdom. pp.360-370, 10.1007/978-3-319-45234-0_33 . hal-01702146

\section{HAL Id: hal-01702146 \\ https://hal.inria.fr/hal-01702146}

Submitted on 6 Feb 2018

HAL is a multi-disciplinary open access archive for the deposit and dissemination of scientific research documents, whether they are published or not. The documents may come from teaching and research institutions in France or abroad, or from public or private research centers.
L'archive ouverte pluridisciplinaire HAL, est destinée au dépôt et à la diffusion de documents scientifiques de niveau recherche, publiés ou non, émanant des établissements d'enseignement et de recherche français ou étrangers, des laboratoires publics ou privés. 


\title{
Impact of Anonymity and Identity Deception on Social Media eWOM
}

\author{
Payal Shrivastava Kapoor ${ }^{1}$, Srinivas Gunta \\ Assistant Professor, FORE School of Management, New Delhi, India \\ \{payalefsm.ac.in\} \\ ${ }^{2}$ Assistant Professor, Indian Institute of Management Indore, India
}

\begin{abstract}
Brand-related consumer to consumer communication, eWOM, is taking place in many forms across the social media space. Rules that governed credibility assessment of brand-related communication, WOM, in the Face to Face context may vary on social media, specifi-cally because of anonymity that is afforded on different social media sites. The current study looks closely on the impact of anonymity in typical eWOM behaviour context on social media by drawing observations from a recent case in point and literature. The paper concludes with a list of relevant factors and propositions that must be tested empirically to draw greater understanding of the phenomenon.
\end{abstract}

Keywords: Anonymous communication, eWOM, credibility, computermediated Communication.

\section{Introduction}

Communication and interaction using social media has spread across cultures globally. Survey data suggests that more than 1.5 billion people, worldwide, are connected via social media communities . Users converse and interact via social media communities, discussion boards, weblogs, social networking sites etc. Increasingly they are turning to social media to socialize and broadcast their views. This has enabled users' of the world to seek and share brand-related experiences and opinions (eWOM) with the click of a few buttons which in turn has significantly altered consumer decision process $[4,15]$.

It is averred that social media is changing the fundamentals of communication in several ways. Intimacy of a face to face $(\mathrm{FtF})$ communication has been replaced with a "broadcast-like ability to communicate with the masses" [ 1, p. 3]. Technology has enabled interpersonal communication to be visible on a more transparent public domain, simultaneously accessible to a very large set of audience. It abundantly supports consumer to consumer conversations, participation, interaction and collaboration which in turn influence behaviour. Therefore while interacting on social media users are hugely influenced by other outside their known circle [10]. Moreover, user interaction, quite like other computer mediated-communication (CMC), may be influenced by 
"disinhibition", enabling them to communicate and behave freely, feel "less restrained, and express themselves more openly" [15, p. 321]. At the same time, similar to other forms of CMC, communication via social media may vary in the degree of anonymity. Anonymity, a social condition, permits user to conceal her identity which further complicates the process of communication on social media. Different social media interface permit different levels of anonymity, which may further reinforce the impact of deindividualisation and hyperpersonal [14].

This article explores the behavioural impact of anonymous eWOM communication by building on a recently observed case of a local establishment - Lemp Brewpub \& Kitchen, Gurgaon, India. An anonymous weblog detailing a bad experience faced by a set of customers went viral which tarnished the reputation of the establishment beyond repair and resulted in its shutting down. This case, simlar to many other recent cases, raises the question of how an anonymous communication (blog post in Lemp's case), reshared by many via various Social Networking Sites(SNSs), can cause serious harm to a brick and mortar establishment ? A single bad experience shared in form of an anonymous blog, damaged Lemp's reputation permanently. This article enquires why despite of anonymity, deindividualisation and possible threat of identity deception, anonymous communication is influential, believable and gathers credibility. The paper explores how in the absence of traditional sources of credibility, users of social media explore alternate heuristics to assess credibility. It is further suggested that these subtle embedded alternate heuristics not only influence user disposition but also their behaviour, observed by the act of resharing of the anonymous blog post. Networkrelated features like homophily and perceived social conformity further provide explanation to the behaviour of resharing. The article concludes with several propositions derived from the experience of Lemp and support found in literature which may be further tested as future research.

The remainder of the article is organised like this: it starts with the details of the Lemp case followed with review of related literature and concludes with propositions.

\section{The Case - Lemp brewpub, Gurgaon, Haryana, India}

\subsection{Anonymous Blog}

On Monday, 10th June 2013, an anonymous blog was posted by a group of eight friends who called themselves "Gurgaon victims" (from here on - group of friends). According to their blog on Sunday, 9th June 2013, based on a promotion they read on a www.zomato.com (a popular online restaurant database and review site, Zomato from here on, Exhibit 1), they decided to go to Lemp Brewpub \& Kitchen, a local pub located in Gurgaon ( satellite city to New Delhi, India), to enjoy a fun filled Hawaiian Brunch. 
Unfortunately Lemp could not deliver the Hawaiian Brunch and a series of occurrences led to altercation between the group of friends and staff. The anonymous blog post recounted how, as the events unfolded, the expected fun filled Hawaiian Brunch turned into a harrowing experience that ended for the group of friends at the local police station, with their parents having to settle the matters. Blog iterated the chronological occurrences of the incident along with photographs of the incident taking place (Exhibit 3 ). There were no photographs of the group of friends themselves. The tonality, flow of details and the facts mentioned in the blog post clearly portrayed the group of friends as victims and denounce the staff of Lemp as a bunch of goons.

\subsection{After Effects}

The anonymous blog went viral and the next day, users across social media sites like Facebook and Twitter woke up to the blog post trending as "How a lunch at Lemp Brewpub turned out to be the most horrid experience ever" ( Exhibit 4) . Users, many who had never dined at Lemp, were sharing and resharing the blog post in abundance. The Facebook page and Twitter handle of Lemp saw no response for a very long time. Within a few hours, most of the users of social media, who had read the blog were completely consumed by it. They had declared Lemp to be the villain. They not only empathised with the group of friends but they extended support by action : posting supportive comments on the blog; sharing police information on where a formal complaint can be lodged; re-sharing the blog with more and more people; cracking "Lemp" jokes on Twitter and elsewhere (Exhibit 5), there by spreading negativity about it; posting bad reviews on Zomato despite having no first hand experience of the pub. As the anonymous blog went viral, it pulled the ratings of Lemp down drastically on Zomato. Within few hours, the number of reviews rose from 382 (before blog) to 900 plus (after blog) with majority of them being negative. The ratings dropped to a poor 1.3 based on 2975 votes (Exhibit 2). Users not only wholeheartedly believe the anonymous blog, they also indulged in supportive behaviour by resharing the post.

\subsection{Epilogue}

Even after months , Lemp failed to recover. On Zomato the ratings stood at a poor 1.3, based on 2101 reviewers . Post this incident whenever similar instances are shared on social media, users of social media are prone to say "don't do another Lemp!" Anonymous bloggers, who concealed their identity, not personally known to many, successfully influenced thousands of social media users and stained the reputation of an establishment in the most serious manner.

\section{$3 \quad$ Theoretical Understanding}




\subsection{Computer-Mediated Communication and Anonymity}

. Web 2.0 and new media now provide many virtual avenues for users to engage and indulge in eWOM, both negative and positive [8]. The above case is an example of other similar cases that have gone viral on social media in the recent times. A single bad experience of a consumer is read, shared and reshared by thousands significantly damaging brand reputation With the spread of internet and the changing media consumption habits, several studies have found eWOM to be more credible, therefore influential, than traditional marketer generated communication [7].

eWOM via social media has intrigued researchers in the recent times for several reasons. From traditional FtF ( face to face) WOM interactions, CMC eWOM diverges significantly. As already stated, users that connect via social media are diverse and the environment "opens up the WOM network from one's immediate contacts to the entire Internet world" $[3$, p. 9] therefore eWOM may take place between users who have no significant prior relationship. Furthermore, just like other CMCs, eWOM via social media may lack both non-verbal and social context cues, yet users adjust to the new environment and use alternative linguistic and other forms of heuristics for judgement $[16,17]$.

Critical enquiry of the current research is the influence of anonymity. Social media interactions take place in environment which may afford different degrees of anonymity to users. SNS like Facebook enables "social interactions through profile-based user accounts", identity creation is quite integral to the site hence user anonymity is lower $[12, p 439,22]$. Weblogs on the other hand provide "a more remote space with less interactivity that may reduce users' awareness of their audiences", hence anonymity varies [9, p 285]: user identity information may be completely anonymous, pseudonymous, or identifiable. Completely anonymous blogs may still offer a few selective self-disclosures [16], as was seen in this case of anonymous blog against Lemp. The anonymous blog revealed no identity information about the bloggers. Level of anonymity of a social media site may further lead to identity deception. Since Identity is separated from physical Self "One can have as many electronic personas as one has time and energy to create" generating convenient possibilities for online deception [5 $\mathrm{p}$. $2,22,9]$

Therefore the critical question that needs to be asked is - Why did the users of social media, who read the anonymous blog, felt positively assured of the intentions and motives of a group of unknowns who reveal no personal information about themselves? In other words, why do anonymous eWOM communication on social media influence when source information is either not shared or could be incorrect?

\subsection{Credibility of Anonymous Social Media eWOM}

The traditional understanding of credibility, based on the extant literature on the subject, is that it may be derived as a result of interaction of source characteristics, message characteristics and receiver characteristics [20]. According to Metzger (2007, p. 2078) 
"credibility of a source or message is a receiver-based judgment which involves both objective judgments of information quality or accuracy as well as subjective perceptions of the source's trustworthiness, expertise, and attractiveness". Therefore it is the interaction of both source credibility, message credibility and receiver based triggers that influences judgements.

Weblogs, Facebook posts and Twitter tweets are the new age platforms that allow users to interact. On these platforms traditional understanding of credibility assessment can vary as the source can be anonymous and messages are technology-enabled and asynchronous. Credibility may not be derived solely from familiarity of source or believing others as they part of a physical social network, it will be assessed using all the other information available on the platform itself [2]. "Variety of stored- information of others", heuristics or cues, are embedded in these platforms which allow assessment of credibility [19,p. 230]. If the heuristics are limited or peculiar, users adapt [21]. Therefore perceptions of credibility may not be based on the traditional sources of credibility, it may be based on all the (limited) informational heuristics available on the social media platform. Specifically, it is posited, readers of the anonymous blog of Lemp assessed credibility based on heuristics embedded within the anonymous blog post itself.

Credibility Heuristics - Source and Message Characteristics. Despite of the blog being anonymous, there were few identity related self-disclosures made in the blog. The bloggers described themselves as "young, 25-year old, working, well educated, aware, well-travelled, well spoken". This indirect self-disclosure helped in building the perception of source credibility. Other set of credibility came from the message itself and manner in which the anonymous blog was written. According to the Language Expectancy Theory, influence of the message can be attributed to its language characteristics. Users are influenced if language characteristics meet or voilate the expected norms even if the message is anonymous [11]. Language of the blog was detailed, refined and informational. Furthermore numerous other heuristics, embedded in the anonymous blog, lend credibility: screenshot of Hawaiian Lunch promotion on Zomato; photograph of the display board; selective negative reviews; photographs of the staff of Lemp carrying a mean disposition; sly looking photograph of the owner with one of his staff member; detailed information of the sequence of events- all worked towards increasing the believabilty of the blog.

Despite the lack of real information regarding the identity of the bloggers, message characteristics and alternate heuristics together made the anonymous blog believable and credible. Therefore following propositions are iterated:

P1 - In the absence of identity information even limited self-disclosures in anonymous communication may lead to significant source credibility. 
P2 - In the absence of identity information, message characterists and content-related heuristics may lead to significant message credibility

P3 - Believability of anonymous blog increases when the source credibility of the 'friend' who has shared the blog is significantly positive

\section{3 eWOM Behaviour - Why share and reshare an anonymous Blog?}

Receiver Charecteristics - Social conformity, Subjective Norms. Anonymous blog was abundantly shared by users and one of the primary reasons for the same was conformity to social behaviour. Social conformity refers to the "act of matching attitudes, beliefs, and behaviours to group norms" [6 p 591]. Where there are numbers the others will join! Users shared as others before them had shared and they were expected to adhere to the subjective norm of resharing. "Subjective norm refers to how a user perceives ways people important to him or her would behave" [13, p-334] and therefore how they must also match their behaviour to meet the social expectation. There is no evidence to reveal identity of the first few people who shared the blog on Facebook and Twitter. May be it was simply a few friends of the blogger, or maybe they were people unknown to them. But once the blog started going viral thousands of people re-shared. They believed it simply because a lot of people before them have already liked, shared, favorited or retweeted it. To that extend there may have been a "flow of source credibility" derived from the immediate network of "friends" who have shared the blog on their timeline, whoes behavioural expectation had to be met Therefore the following proposition is iterated:

P4 - In the absence of identity information subjective norms are positively associated with behaviour of resharing by the user

Homophily. Homophily, or the perception of similarity [14], also had a role to play for the spread of the anonymous blog. Blogger by calling themselves "young and 25 year something" tried to connect with others like them. Users may have perceived similarity of lifestyle, age and background. Therefore homophily, perception of similarity, further influenced the reshare behaviour. Therefore the following proposition is iterated:

P5 - Perception of homophily with the blogger, based on limited self-disclosures, is significantly related to the behaviour of resharing by the user

\section{Conclusion and Future Research}

This article discussed the behavioural impact of anonymous communication as observed in the case of Lemp. The article draws undersanding from literature for a real case of a business establishment that loses its reputation permanently. The article in 
accordance with the traditional understanding of credibility, as a source, message and receiver characteristic based judgement, identified factors that would lead to believability of anonymous eWOM. The anonymous blog may have damaged Lemp's reputation significantly and permanently. The article highlights despite of absence of pre-existing familiarity, trust and anonymity, credibility can be established based on several subtle alternate heuristics embedded in the communication. It further explained how receiver network-related features like homophily, subjective norms and social conformity may be responsible for the anonymous blog going viral. With the help of the observations of this case and literature the article posites several research directions that can be explored.

New media has altered several aspects of interpersonal communication and influence. Consumer to consumer communication is taking place in abundance and marketers need to appropriately listen and engage. A single bad experience is capable of damaging an organisations reputation severely, as was seen in the case sited. Anonymity afforded by social media sites needs to be understood better so that marketers can have better control over their brands reputation. Therefore this paper is an attempt to have greater understanding of this phenomenon. Empirical verification of the propositions can lead to greater understanding of behavioural impacts of anonymous communication.

\section{References}

1. Blackshaw, P., \& Nazzaro, M. (2006). Consumer-generated media (CGM) 101: Wordof-mouth in the age of the web-fortified consumer. A Nielsen BuzzMetrics White Paper, Second Edition, Spring.

2. Castillo, C., Mendoza, M., \& Poblete, B. (2011). Information Credibility on Twitter. Proceeding of WWW 2011, March 28-April 1, 2011, Hyderabad, India. ACM 978-14503-0632-4/11/03

3. Cheung, M. Y., Luo, C., Sia, C. L., \& Chen, H. (2009). Credibility of electronic wordof-mouth: Informational and normative determinants of on-line consumer recommendations. International Journal of Electronic Commerce, 13(4), 9-38.

4. Chu, S. C., \& Kim, Y. (2011). Determinants of consumer engagement in electronic word-of-mouth (eWOM) in social networking sites. International journal of Advertising, 30(1), 47-75.

5. Donath, J. S. (1999). Identity and deception in the virtual community. Communities in cyberspace, 1996, 29-59.

6. Cialdini, R. B., \& Goldstein, N. J. (2004). Social influence: Compliance and conformity. Annu. Rev. Psychol., 55, 591-621.

7. Hajli, M. N., Sims, J., Featherman, M., \& Love, P. E. (2015). Credibility of information in online communities. Journal of Strategic Marketing, 23(3), 238-253.

8. Hennig-Thurau, T., Gwinner, K. P., Walsh, G., \& Gremler, D. D. (2004). Electronic word-of-mouth via consumer-opinion platforms: What motivates consumers to articulate themselves on the Internet? Journal of interactive marketing, 18(1), 38-52.

9. Hollenbaugh, E. E., \& Everett, M. K. (2013). The effects of anonymity on selfdisclosure in blogs: An application of the online disinhibition effect. Journal of Computer-Mediated Communication, 18(3), 283-302. 
10. Jansen, B. J..Zhang, M.,Sobel, K., \& Chowdury, A. (2009). Twitter Power: Tweets as Electronic Word of Mouth. Journal of the American Society for Information Science and Technology, 60( 11), 2169-2188.

11. Jensen, M. L., Averbeck, J. M., Zhang, Z., \& Wright, K. B. (2013). Credibility of anonymous online product reviews: A language expectancy perspective. Journal of Management Information Systems, 30(1), 293-324.

12. Keenan, A., \& Shiri, A. (2009). Sociability and social interaction on social networking websites. Library Review, 58(6), 438-450.

13. Lee, S. Y., Hansen, S. S., \& Lee, J. K. (2016). What makes us click "like" on Facebook? Examining psychological, technological, and motivational factors on virtual endorsement. Computer Communications, 73, 332-341.

14. McCroskey, J. C., Richmond, V. P., \& Daly, J. A. (1975). The development of a measure of perceived homophily in interpersonal communication. Human Communication Research, 1(4), 323-332.

15. Metzger, M. J. (2007). Making sense of credibility on the Web: Models for evaluating online information and recommendations for future research. Journal of the American Society for Information Science and Technology, 58(13),2078-2091.

16. Qian, H., \& Scott, C. R. (2007). Anonymity and Self-Disclosure on Weblogs. Journal of Computer-Mediated Communication, 12(4), 1428-1451.

17. Suler, J. (2004). The online disinhibition effect. Cyberpsychology \& behavior, 7(3), 321-326.

18. Walther, J. B. (1996). Computer-mediated communication impersonal, interpersonal, and hyperpersonal interaction. Communication research, 23(1), 3-43.

19. Walther, J. B., Van Der Heide, B., Hamel, L. M., \& Shulman, H. C. (2009). SelfGenerated Versus Other-Generated Statements and Impressions in Computer-Mediated Communication A Test of Warranting Theory Using Facebook. Communication Research, 36(2), 229-253.

20. Wathen, C. N., \& Burkell, J. (2002). Believe it or not: Factors influencing credibility on the Web. Journal of the American society for information science and technology, 53(2), 134-144.

21. Westerman, D., Spence, P. R., \& Van Der Heide, B. (2012). A social network as information: The effect of system generated reports of connectedness on credibility on Twitter. Computers in Human Behavior, 28(1), 199-206.

22. Zhao, S., Grasmuck, S., \& Martin, J. (2008). Identity construction on Facebook: Digital empowerment in anchored relationships. Computers in human behavior, 24(5), 18161836.

\section{Exhibits}

\section{$1 \quad$ Zomato \& Its User Review and Rating Mechanism}

Zomato started its journey as an online restaurant guide under the name of Foodiebay.com in 2008. After aiding the taste buds of Delhi NCR food lovers it expanded to other cities such as Kolkata and Mumbai ${ }^{1}$ and soon, other prominent cities across the country as well. In 2010, with funding from Info Edge, it rebranded itself to

\footnotetext{
${ }^{1}$ http://www.dnaindia.com/lifestyle/report-for-the-love-of-food-1284846 retrieved on 28th Nov 2013.
} 
Zomato $^{2}$ and 2012 saw it launching its first international services. ${ }^{3}$ With additional funding from Sequoia Capital it has forayed into many other international markets and is expected to eat into the market share of Yelp. ${ }^{4}$ It has the following services; it is a restaurant database and guide which allows a user to search information, allows uers to review restuarants and recently it has started online food ordering service

Restaurants, pubs and clubs detailed on Zomato can be rated by a reviewer on a scale of 1 to 5 , where ratings denote the following:

\begin{tabular}{|c|c|c|c|c|c|c|c|c|c|}
\hline Rating & 1.0 & 1.5 & 2.0 & 2.5 & 3.0 & 3.5 & 4.0 & 4.5 & 5.0 \\
\hline Significance & Avoid & Very Bad & Blah ! & Well.. & Average & Good enough & Great & Loved it ! & Insane ! \\
\hline
\end{tabular}

A registered user may also leave a review of minimum 50 words. Registered users are categorised as: Foodie; Big Foodie; Super Foodie; Connoisseur. Based on a user's engagement with the site, he/she may get upgraded to the next levels. ${ }^{5}$

\section{2}

\section{Lemp's Rating on Zomato}

Home / Delhi NCR / Gurgaon / Sector 30 / Lemp Brewpub \& Kitchen

\section{Lemp Brewpub \& Kitchen}

C) +919899692000, +919971366401

- 535 user reviews Write your review for Lemp Brewpub \& Kitchen

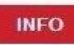

(a) thangs 12 Noon to 12 Midnight

Source: https://www.zomato.com/ncr/restaurants?q=Lemp retrieved on June $13^{\text {th }} 2013$

${ }^{2}$ http://www.nextbigwhat.com/foodiebay-rebrands-to-Zomato-297/ retrieved on $28^{\text {th }}$ Nov 2013

${ }^{3}$ http://www.khaleejtimes.com/kt-article-display-

1.asp?xfile=/data/todayevent/2012/August/todayevent_August29.xml\&section=todayevent retrieved on $28^{\text {th }}$ Nov 2013

${ }^{4}$ http://techcrunch.com/2013/11/06/Zomato/ retrieved on $28^{\text {th }}$ Nov 2013

${ }^{5}$ http://www.Zomato.com/leaderboard retrieved on 28th Nov 2013 
Anonymous Blog Post (First Page)

The entis incident in detal

II/06/13 II:St $n$

Yesterday

The entire incident in detail

For a ict of reascre, we have thought a lot before witing this. it is a very detailed acoourt and we suggest you read it with petience. There is a ict to leam for us customers and a lot to be ieamt by the recteurant owners communty aba.

A few of us friends (young, 26-year oid, working, well educated, aware, well traveled, wel spoken) were searching for a place to go to for Sunday brunch and on Zomato.com we came acroes a "Hieweilan Sunday Brunch" st Lemp Brewpub, Gurgocn. We decided to try out the Hawaion brunch. As you can oee from the imege below, the coet is $\mathrm{Re} .999$ al inclualve of taves, and the same wac sloo confimed to us by the manegsr, Mr. Robin.

To put it out there, it wacn't the first time we were going to Lemp.

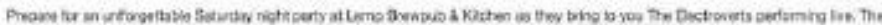

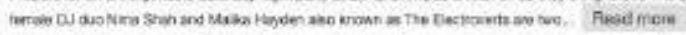

Emotianinat Nuste

\section{9 unt Hawailian Sunday Brunch}

Fucessm 12 roon to 4FM

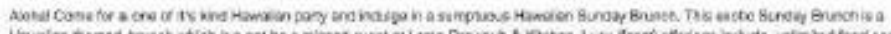

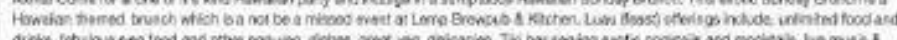

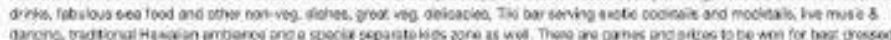

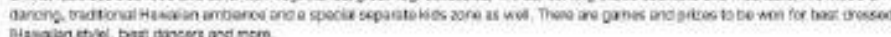

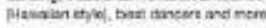

Proes As. 999 A1

isnay Bersei

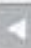

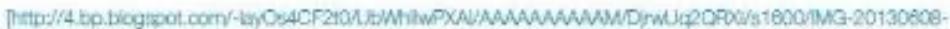
WR.000 T.jpg!

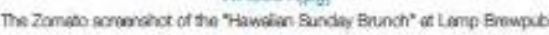

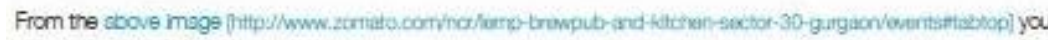
con read the promices:

Hawaiion food - NCNE to be found.

Thi bar serving evctio oocktalis - there was no such bar.

Live musio and dencing - There was no musio playng st all. After we acked they swtched on the speckers and

regular music played in the background. For the dencing. there were never any pisns for danoers. On a serious note we were told by the maneger, Robin, that customers were the ones supposed to dance.

Source: http://lempexperience.blogpost.in/2013/06/the-entire-incident-in-detail.html retrieved $\underline{12 \text { th June } 2013}$ 
Immediate Social Media Reactions

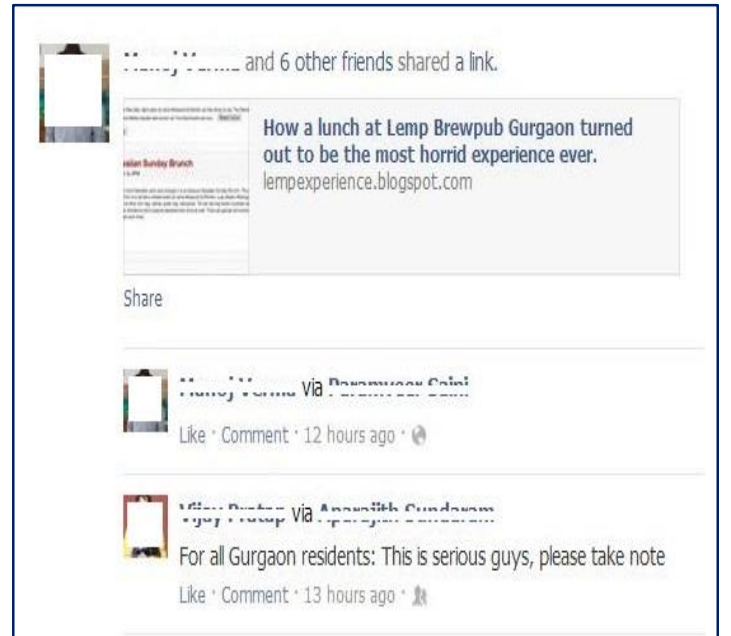

\begin{tabular}{|c|c|}
\hline 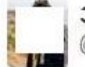 & Follow \\
\hline \multicolumn{2}{|c|}{$\begin{array}{l}\text { This is Shocking --> How a lunch at Lemp Brewpub } \\
\text { Gurgaon turned out to be the most horrid experience ever } \\
\text { lempexperience.blogspot.in } / 2013 / 06 / \text { the-en... } \\
\text { 3:01 PM - } 11 \text { Jun } 2013\end{array}$} \\
\hline 1 FAVORITE & \& \\
\hline 3 & Follow \\
\hline \multicolumn{2}{|c|}{$\begin{array}{l}\text { Where NEVER to go for food - Lemp Brewpub in Gurgaon: } \\
\text { ow.ly/lUnPH - via @ deejTHtraveller @ beastoftraal - How } \\
\text { terrible! } \\
\text { 1:23 PM - } 11 \text { Jun } 2013\end{array}$} \\
\hline 5 RETWEETS & \& $17 *$ \\
\hline
\end{tabular}

Source (Left to Right): www.facebook.com retrieved 13 ${ }^{\text {th }}$ June 2013; https://twitter.com/search?q=lemp\&src=typd retrieved $13^{\text {th }}$ June 2013.

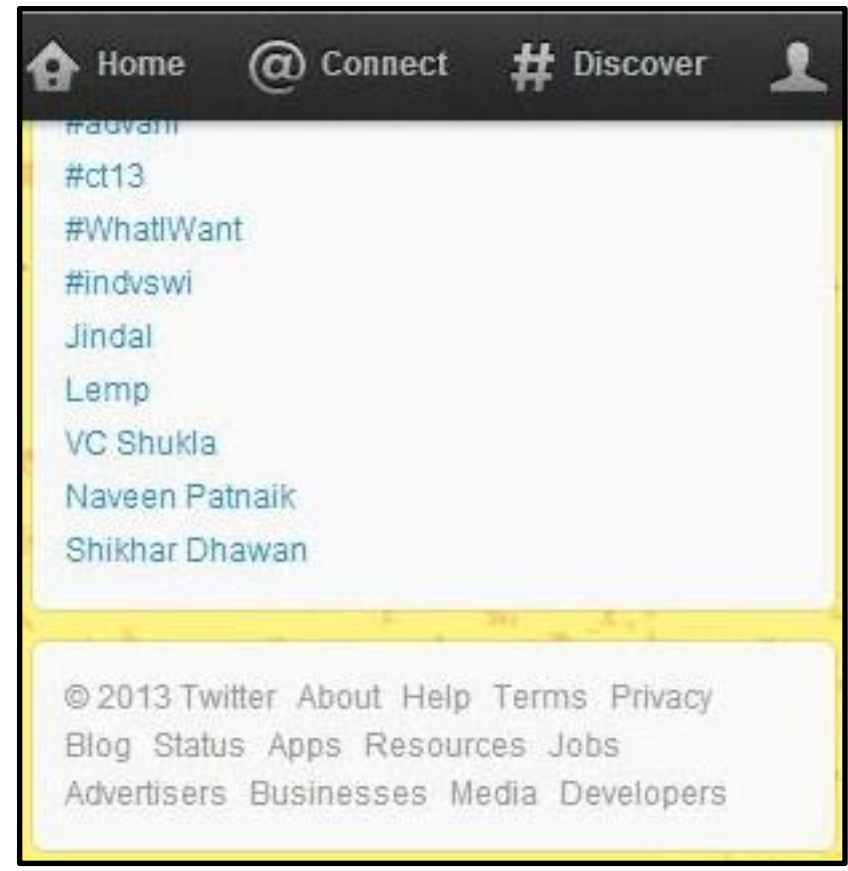

Source: https://twitter.com/ retrieved $11^{\text {th }}$ June 2013 
5

Don't Do a Lemp!

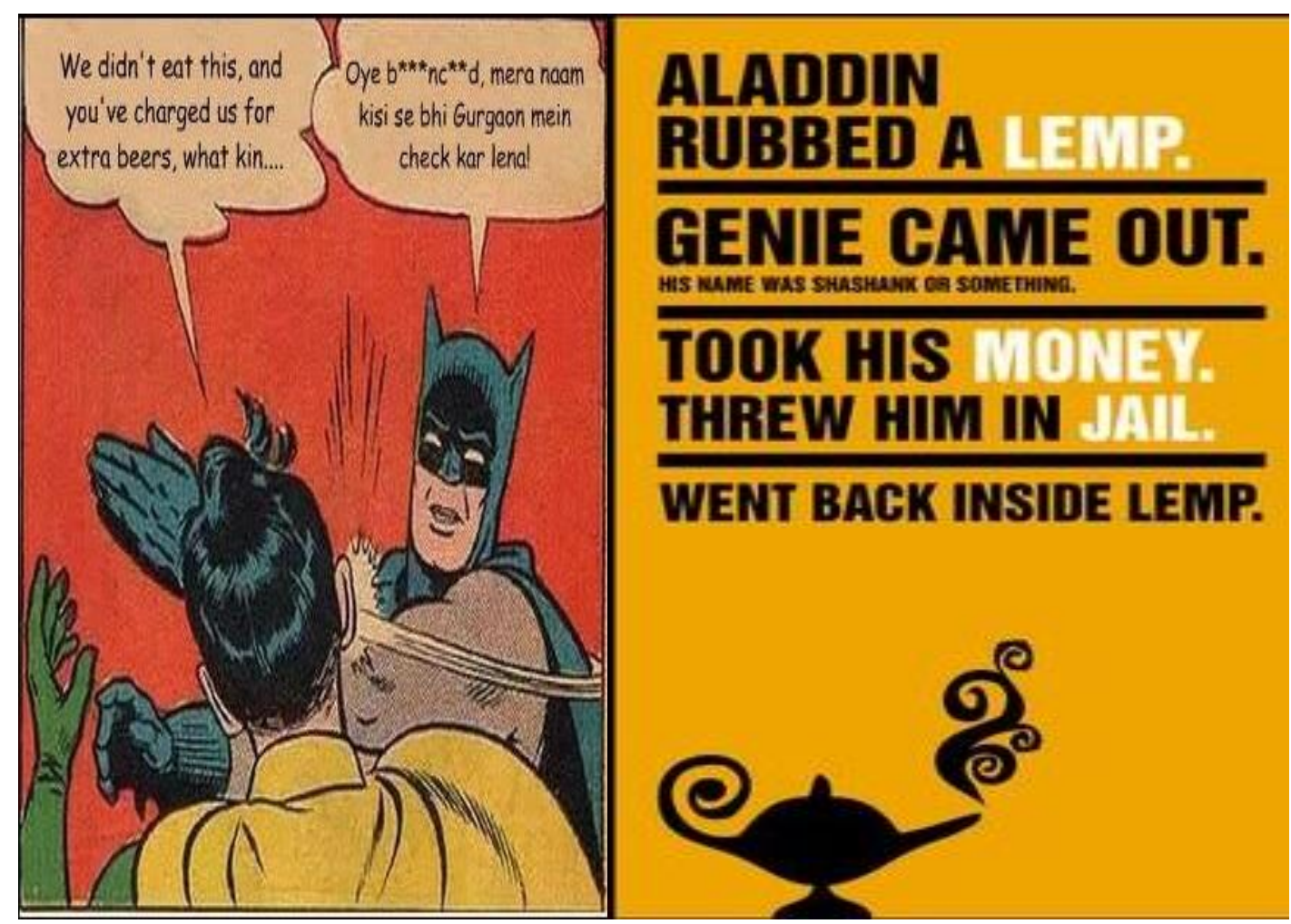

Source (Left to right): https://twitter.com/NitinBajaj/status/344449051997138944/photo/1 retrieved on 7th September 2013;

https://twitter.com/asraghunath/status/344817283119599617/photo/1 retrieved on 7th September 2013 